JOSEPH CONRAD AND THE WEST 


\section{JOSEPH CONRAD AND \\ THE WEST}

Signs of Empire

\section{Jacques Darras}

Translated from the French

by Anne Luyat and Jacques Darras

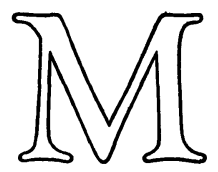




\section{For Anne-Marie}

(C) Jacques Darras 1982

All rights reserved. No part of this publication may be reproduced or transmitted, in any form or by any means, without permission

First published 1982 by THE MACMILLAN PRESS LTD London and Basingstoke Companies and representatives throughout the world

ISBN 978-o-333-65327-2 ISBN 978-1-349-26510-7 (eBook) DOI 10.1007/978-1-349-26510-7 


\section{Contents}

I Introduction I

PART I MYTHICAL EAST 9

2 An Intoxicating Tale 1 I

The Tarnished Blazon II

An Intoxicating Tale 13

Second East $\quad 17$

3 The Enclosure of Death 23

PART II THE COLONIAL IMPOSTURE 35

4 Deviations $\quad 37$

Maps $\quad 39$

The Book 43

The Round Table $\quad 47$

The Holy Grail 5

5 Reversals 53

'Civis Romanus Sum'

'Mr Stanley, I Presume?' 63

The Minstrel of the East $\quad 69$

6 Short-Cuts $\quad 75$

The Short-Circuit of Humour $\quad 76$

The Allegorical Short-Cut $\quad 79$

The Dramatic Short-Cut 8 8I

The Ideological Short-Cut $\quad 84$

7 Full Circle 93

PART III ANALYSIS OF THE WEST 97

8 Tribal and Economic Exchanges 99

9 Mining and Refining Reality 109

Contraction $\quad$ I09

Sediment II I

Frames $\quad$ II3

Process 114

$\begin{array}{ll}\text { Fractures } & \text { I I } 7\end{array}$ 
Io The Power of Writing

Power, Writing, Sacrifice

Power, Torture, Bodies

I 22

Narration, Voyeurism, Censorship

126

Writing, Violence, Suffering

I I Conclusion

Notes

145

Bibliography

I 5 I

Index 